\title{
Extrahepatic Synthesis of Lipoproteins of Plasma and Chyle: Role of the Intestine*
}

\author{
Paul S. Roheim, $\nmid$ Lewis I. Gidez, $\ddagger$ and Howard A. Eder \\ (From the Departments of Medicine, Physiology, and Biochemistry, Albert Einstein College \\ of Medicine, New York, N. Y.)
}

Several groups of investigators (1-3) have shown that the protein portion of the plasma lipoproteins of the rat can be synthesized by the liver. The present studies were undertaken to determine whether any lipoprotein synthesis can occur in the absence of the liver. Previous work by Bragdon (4) and by Rodbell, Fredrickson, and Ono (5) has suggested intestinal synthesis of lipoproteins. Since their studies were carried out in intact animals, however, the liver could not be excluded as a source of these proteins. We have therefore measured the synthesis of the protein component of the lipoproteins of chyle and plasma in hepatectomized dogs.

\section{Methods}

Male mongrel dogs weighing 12 to $18.5 \mathrm{~kg}$ were fasted for 18 hours before operation. The dogs were anesthetized with pentobarbital (35 $\mathrm{mg}$ per $\mathrm{kg}$ iv). The following types of preparations were used: a) hepatectomized dogs, b) hepatectomized dogs with thoracic duct fistulas, $c$ ) eviscerated dogs, and $d$ ) an anesthetized normal control.

A one-stage hepatectomy was performed (6) in which a portacaval shunt was established and the liver removed after it had been stripped from the intrahepatic vena cava, which was left in situ. In the dogs in which the thoracic duct was cannulated, 50 to $100 \mathrm{ml}$ of cream was fed 2 hours before the administration of anesthesia. A polyethylene tube was inserted into the thoracic duct in the neck, and the lymph was collected continuously; hepatectomy was then performed. In animals on which abdominal evisceration was performed, the stomach, in-

* Submitted for publication April 10, 1964; accepted November 18, 1965.

Presented in part at the meeting of the American Physiological Society, April 1962.

This study was supported by research grant HE-02965 and training grant HTS-5273 from the National Heart Institute and by a grant from the American Heart Association.

$\dagger$ Established Investigator, American Heart Association.

¥ Career Scientist, Health Research Council of the City of New York (contract I-353). testine, spleen, and pancreas as well as the liver were removed (7). All experiments were carried out within 2 hours after completion of the operation.

L-Lysine-U- ${ }^{11} \mathrm{C}^{1}$ was dissolved in Ringer's solution and given intravenously ( 5.6 to $10.6 \mu \mathrm{c}$ per $\mathrm{kg}$ ) at the beginning of the experimental period. All of the isotopic data obtained have been corrected to a standard dose of $10 \mu \mathrm{c}$ of ${ }^{14} \mathrm{C}$ administered per $\mathrm{kg}$ body weight. One hepatectomized animal (no. 8) with a thoracic duct fistula received by stomach tube $315 \mu \mathrm{c}$ of palmitic acid$9,10-{ }^{8} \mathrm{H}^{2}$ that had been purified by thin layer chromatography (hexane-diethyl ether-acetic acid, $83: 16: 1$ ). The acid was administered in $50 \mathrm{ml}$ of cream.

The animals were exsanguinated by bleeding from the carotid artery, and the lipoproteins of the plasma and the thoracic duct lymph were separated by ultracentrifugal flotation according to the method of Havel, Eder, and Bragdon (8).

The amount of protein and the radioactivity of the proteins were determined by a modification (9) of the method of Radding and Steinberg (2).

\section{Results}

Table I shows that in hepatectomized animals there was significant incorporation of radioactivity into all plasma lipoprotein fractions with the highest specific activities in the $D<1.019$ fraction. In the intact dog there was far greater incorporation: the specific activities of the proteins were 20 to 100 times greater than those of the lipoproteins of the hepatectomized dogs. When evisceration was performed, there was no incorporation into the $\mathrm{D}<1.019$ lipoprotein fractions although the plasma lipoprotein fractions of D 1.019 to 1.063 and D 1.063 to 1.21 had activities similar to those found in the hepatectomized animals. In both hepatectomized and eviscerated animals the $\mathrm{D}>$ 1.21 plasma proteins were labeled after 240 minutes.

Subsequent studies were carried out in dogs whose thoracic ducts had been cannulated. Lymph

1 Obtained from Volk Radiochemical Co., Chicago, IIl., and New England Nuclear Corp., Boston, Mass.

2 New England Nuclear Corp. 
TABLE I

Incorporation of lysine- $U \cdot{ }^{14} C$ into lipoproteins and other proteins of dog plasma

\begin{tabular}{|c|c|c|c|c|c|}
\hline \multirow[b]{2}{*}{$\begin{array}{l}\text { Experimental } \\
\text { procedure }\end{array}$} & \multirow{2}{*}{$\begin{array}{l}\text { Time after } \\
\text { lysine ad- } \\
\text { ministration }\end{array}$} & \multicolumn{4}{|c|}{ Specific activity of proteins } \\
\hline & & $\mathrm{D}<1.019$ & D $1.019-$ & $\mathrm{D}_{1.21}^{1.063-}$ & $\mathrm{D}>1.21$ \\
\hline & minutes & \multicolumn{4}{|c|}{$\because d p m / m g$} \\
\hline $\begin{array}{l}\text { Nonoperated control } \\
\text { Hepatectomy } \\
\text { Hepatectomy } \\
\text { Evisceration }\end{array}$ & $\begin{array}{r}240 \\
90 \\
270 \\
240\end{array}$ & $\begin{array}{r}9,930 \\
400 \\
510 \\
0\end{array}$ & $\begin{array}{r}3,720 \\
50 \\
50 \\
40\end{array}$ & $\begin{array}{r}1,880 \\
30 \\
90 \\
60\end{array}$ & $\begin{array}{r}* \\
0 \\
340 \\
70\end{array}$ \\
\hline
\end{tabular}

* Not measured.

TABLE II

Incorporation of lysine- $U-{ }^{14} C$ into lipoproteins and other proteins of plasma and thoracic duct lymph of hepatectomized dogs with thoracic duct fistulas

\begin{tabular}{|c|c|c|c|c|c|c|}
\hline \multirow{2}{*}{$\begin{array}{c}\text { Experi- } \\
\text { ment } \\
\text { no. }\end{array}$} & \multirow{2}{*}{$\begin{array}{l}\text { Time after } \\
\text { lysine ad- } \\
\text { ministration }\end{array}$} & \multirow[b]{2}{*}{ Samples } & \multicolumn{4}{|c|}{ Specific activity of proteins } \\
\hline & & & $\mathrm{D}<1.019$ & $\begin{array}{c}\text { D 1.019- } \\
1.063\end{array}$ & D $1.063-$ & $D>1.21$ \\
\hline \multicolumn{3}{|c|}{ minutes } & \multicolumn{4}{|c|}{$d p m / m g$} \\
\hline 4 & 240 & Plasma & 0 & 57 & 117 & $*$ \\
\hline & $130-240$ & Lymph & 2,030 & 130 & 200 & 290 \\
\hline \multirow[t]{2}{*}{7} & 240 & Plasma & $\begin{array}{r}2,000 \\
0\end{array}$ & 70 & 160 & 30 \\
\hline & $75-165$ & Lymph & 320 & 580 & 880 & 130 \\
\hline \multirow[t]{2}{*}{8} & 180 & Plasma & 0 & 40 & 30 & 40 \\
\hline & $60-180$ & Lymph $\dagger$ & $550 \ddagger$ & 50 & 60 & 170 \\
\hline
\end{tabular}

* Not measured.

$\dagger$ The lymph was centrifuged at D 1.006 for 30 minutes at $30,000 \times g$ before separating the other lipoprotein fractions. $\ddagger D=1.006$ to 1.019 .

was collected during the experimental periods. In Table II are shown the results of three experiments with these dogs. No radioactivity was found in the plasma lipoproteins of $\mathrm{D}<1.019$, but the other two plasma lipoprotein fractions had specific activities comparable to those of hepatectomized dogs (Table I). In two experiments the specific activity of the $D<1.019$ fraction of the lymph was appreciable and considerably higher than in the other lymph lipoprotein fractions. In one experiment the specific activity of the $\mathrm{D}<$ 1.019 fraction was slightly less than that of the other two fractions. The radioactivity present in the $\mathrm{D}<1.019$ fraction of the plasma shown in Table I appears to have been derived entirely from the lymph, since when the lymph was diverted, no radioactivity was found in the $D<1.019$ lipoproteins of the plasma.

In experiment $8,315 \mu \mathrm{c}$ of palmitic acid-9, $10-{ }^{8} \mathrm{H}$ dissolved in $50 \mathrm{ml}$ of cream was given by stomach tube at the same time the lysine- ${ }^{14} \mathrm{C}$ was administered. The radioactivity recovered in the tri- glycerides of the lymph and plasma amounted to less than $0.01 \%$ of the administered isotope.

\section{Discussion}

In all six dogs subjected to hepatectomy, synthesis of plasma lipoproteins occurred. In the two dogs on which only hepatectomy was performed, there was incorporation of lysine into all plasma lipoprotein fractions with the highest activity found in the $\mathrm{D}<1.019$ fraction. In the four experiments in which evisceration or diversion of thoracic duct lymph occurred, there was labeling of the D 1.019 to 1.063 and of the D 1.063 to 1.21 plasma lipoproteins but not of the $\mathrm{D}<$ 1.019 lipoproteins. However, the $\mathrm{D}<1.019$ lipoproteins in the thoracic duct lymph obtained from these dogs were labeled; the specific activity in two of the animals was considerably higher than that of the other lipoprotein fractions. These experiments indicate that extrahepatic synthesis of lipoproteins occurs. They further suggest that the intestine is the major extrahepatic site of synthe- 
sis of the $\mathrm{D}<1.019$ lipoproteins but that synthesis of the D 1.019 to 1.063 and D 1.063 to 1.21 lipoproteins occurs in other tissues also. It is possible that some of the radioactivity found in the D 1.019 to 1.063 and $\mathrm{D} 1.063$ to 1.21 lipoproteins may be due to contamination of $\mathrm{D}>1.21$ proteins, which include $\gamma$-globulin. However, Roheim, Miller, and Eder (9) have shown that the extent of such contamination would be insufficient to explain the amount of radioactivity found in these fractions in our present experiments. Earlier studies by Bragdon (4) and by Rodbell and his colleagues (5) had suggested that the formation of the protein of the chylomicrons occurred in the intestine. The latter workers pointed out that in the intact animal it was impossible to exclude the contribution of the liver. In our present studies, in which hepatic synthesis was definitely excluded, the newly synthesized lipoproteins in the thoracic duct lymph were undoubtedly derived from the intestine. These findings are compatible with observations by both Rodbell and colleagues (5) and by Isselbacher and Budz (10) showing that intestinal tissue can incorporate amino acids into lipoproteins in vitro. Isselbacher and Budz raised the question of whether the lipoproteins synthesized in vitro are similar to those present in the chylomicrons during fat absorption. Our experiments do not answer this question, since in these dogs there does not appear to be any significant absorption of fat during the period of lymph collection. This may be due to a combination of factors such as impaired gastrointestinal motility, changes in the intestine due to operative trauma, or the exclusion of the bile. The fact that the specific activity of the $\mathrm{D}<1.019$ lipoproteins of the lymph is so much higher than that of any of the other plasma proteins suggests that the $\mathrm{D}<1.019$ lipoproteins are not derived from plasma proteins or lipoproteins unless by some very selective process whereby a small fraction of plasma proteins of very high specific activity is utilized.

In somewhat comparable experiments Lindsey and Wilson (11) measured the incorporation of acetate- ${ }^{14} \mathrm{C}$ into the intestinal lymph of cholesterolfed rats. They found considerable radioactivity in the cholesterol of the lymph and virtually none in the plasma. In the intact cholesterol-fed animal there was some labeled cholesterol in the plasma, but this was undoubtedly derived from the in- testine. It thus appears that the intestine is the major site of extrahepatic synthesis of at least two of the components of the lipoproteins.

Comparison of lipoprotein synthesis in the intact control animal with synthesis in the hepatectomized animals, as well as the other data from liver perfusions $(1,3)$, shows that the liver has a great capacity for lipoprotein synthesis, which probably exceeds that of other organs, including the intestine. However, exact quantitation of lipoprotein synthesis by various tissues is not possible from these studies because of the marked physiologic changes secondary to operative trauma. Furthermore, hepatectomy may well alter the rate of removal of lipoproteins from the plasma as well as the rate of turnover of the labeled amino acid, and it would appear from the data of Lindsey and Wilson that diversion of the bile may decrease the release of lipoprotein into the intestinal lymph (11).

It is of interest to compare the liver and intestine with respect to lipid metabolism. Both tissues are of the same embryologic origin, and both appear to be the only organs from which appreciable amounts of fatty acids are transported as glycerides contained in very low density lipoproteins. Apparently certain factors controlling the release of lipoproteins from liver may also be operative in the intestine. Thus, the release of triglyceride in very low density lipoproteins from the liver is stimulated by increased uptake of free fatty acid by the liver $(12,13)$. Similarly an increase of the amount of free fatty acid entering intestinal cells, as after a fat meal, increases the release of lipoprotein in the form of chylomicrons. The transport of lipid from the liver is dependent upon the synthesis of lipoproteins (14), and recent studies suggest that this is also true of the intestine (15).

\section{Summary}

Extrahepatic synthesis of plasma lipoproteins was studied by measuring the incorporation of lysine$\mathrm{U}-{ }^{14} \mathrm{C}$ into the lipoproteins of hepatectomized and abdominally eviscerated dogs. In hepatectomized dogs there was incorporation of the lysine into all lipoprotein fractions but considerably less than in the intact animal. The highest rate of incorporation was in the $\mathrm{D}<1.019$ lipoprotein fraction. In an abdominally eviscerated dog there was incor- 
poration into the $\mathrm{D} 1.019$ to 1.063 and $\mathrm{D} 1.063$ to 1.21 fractions but not into the $D<1.019$ fraction. When the thoracic duct in hepatectomized dogs was cannulated and the lymph diverted, no activity was found in the $D<1.019$ fraction of the plasma lipoproteins, but this fraction in the thoracic duct lymph was highly labeled. The findings suggest that the liver and the intestine are probably the sole sites of synthesis of the very low density lipoproteins.

\section{Acknowledgments}

We are indebted to Dr. Seymour Alpert and Dr. Seymour Tindel for the surgical preparations and to Mrs. Libby Miller and Mrs. Ann Lorenz for their competent assistance.

\section{References}

1. Marsh, J. B., and A. F. Whereat. The synthesis of plasma lipoprotein by rat liver. J. biol. Chem. 1959, 234, 3196.

2. Radding, C. M., and D. Steinberg. Studies on the synthesis and secretion of serum lipoproteins by rat liver slices. J. clin. Invest. 1960, 39, 1560.

3. Haft, D. E., P. S. Roheim, A. White, and H. A. Eder. Plasma lipoprotein metabolism in perfused rat livers. I. Protein synthesis and entry into the plasma. J. clin. Invest. 1962, 41, 842.

4. Bragdon, J. H. On the composition of chyle chylomicrons. J. Lab. clin. Med. 1958, 52, 564.
5. Rodbell, M., D. S. Fredrickson, and K. Ono. Metabolism of chylomicron proteins in the dog. J. biol. Chem. 1959, 234, 567.

6. Starzl, T. E., V. M. Bernhard, R. Benvenuto, and N. Cortes. A new method of one-stage hepatectomy for dogs. Surgery 1959, 46, 880.

7. Markowitz, J., J. Archibald, and H. G. Downie. Experimental Surgery, 4th ed. Baltimore, Williams \& Wilkins, 1959, p. 866.

8. Havel, R. J., H. A. Eder, and J. H. Bragdon. The distribution and chemical composition of ultracentrifugally separated lipoproteins in human serum. J. clin. Invest. 1955, 34, 1345.

9. Roheim, P. S., L. Miller, and H. A. Eder. The formation of plasma lipoproteins from apoprotein in plasma. J. biol. Chem. 1965, 240, 2994.

10. Isselbacher, K. J., and D. M. Budz. Synthesis of lipoproteins by rat intestinal mucosa. Nature (Lond.) 1963, 200, 364.

11. Lindsey, C. A., Jr., and J. D. Wilson. Evidence for a contribution by the intestinal wall to the serum cholesterol of the rat. J. Lipid Res. 1965, 6, 173.

12. Gidez, L. I., P. S. Roheim, and H. A. Eder. Effect of plasma free fatty acid concentrations on triglyceride synthesis by the perfused liver. Fed. Proc. 1962, 21, 289.

13. Nestel, P. J., and D. Steinberg. Fate of palmitate and of linoleate perfused through the isolated rat liver at high concentrations. J. Lipid Res. 1963, $4,461$.

14. Eder, H. A., P. S. Roheim, and S. Switzer. An apoprotein of the lipoproteins. Trans. Ass. Amer. Phycns 1964, 77, 259.

15. Isselbacher, K. J. Metabolism and transport of lipid by intestinal mucosa. Fed. Proc. 1965, 24, 16.

\section{SPECIAL NOTICE TO SUBSCRIBERS}

Post Offices will no longer forward the Journal when you move.

Please notify The Journal of Clinical Investigation, Business Office, 10 Stoughton Street, Boston, Mass. 02118, at once when you have a change of address, and do not omit the Zip Code number. 